\title{
REVIEW ARTICLE: \\ Eighteenth Century Amazons
}

\author{
Rosalind Delmar
}

\section{A Woman of No Character, An Autobiography of Mrs Manley}

Fidelis Morgan

Faber \& Faber London, 1987

ISBN $0571139345 £ 9.95 \mathrm{Hbk}, 176 \mathrm{pp}$

\author{
Love Letters Between a Nobleman and His Sister \\ Aphra Behn \\ New Introduction by Maureen Duffy \\ Virago Press London, 1987 \\ ISBN $0860688232 £ 6.95 \mathrm{Pbk}, 461 \mathrm{pp}$
}

\section{The Celebrated Mary Astell}

\section{Ruth Perry}

University of Chicago Press Chicago, 1986

ISBN $0226660958 £ 13.95 \mathrm{Pbk}, 549 \mathrm{pp}$

\section{The First English Feminist: Reflections on Marriage and Other Writings by Mary Astell \\ Bridget Hill (Ed) \\ Gower/Maurice Temple Smith London, 1986 \\ ISBN $0566050900 £ 15 \mathrm{Hbk}, 235 \mathrm{pp}$}

\section{Sexuality in Eighteenth Century Britain}

Paul Gabriel Boucé (Ed)

Manchester University Press Manchester, 1982

$0719008654 £ 18.50 \mathrm{Hbk}, 262 \mathrm{pp}$

In June 1709, The Tatler, under the editorship of Richard Steele, published a short satire about how a young man has been able to ingratiate himself into a nunnery for young ladies because Madonella, the woman in charge, is so far above the world as not to understand its 
wicked ways. Three months later another satire poked fun at projects for women's colleges and at three women named as involved in such a scheme: Mary Astell (the Madonella of the earlier piece), Mrs Delarivier Manley and Elizabeth Elstob. The inapposite nature of this 'Modern Amazonian' enterprise is once more a source of merriment: instead of Scissors, Needles and Samplers; Pens, Compasses, Quadrants, Books, Manuscripts, Greek, Latin and Hebrew, are to take up their whole time.'

After all these years it is difficult to join Mr Tatler, be he Richard Steele (who disclaimed authorship) or Jonathan Swift, in their laughter at the ladies, but it is possible to marvel at the longevity of the joke. The unrealistic Duenna, so airy-fairy she fails to spot a rake when she sees one, expects women to forsake both dressmaking and men for an educational project of all things! All that is needed to wreck her hopes are a few good-looking and plausible men: their superior attractive power will conquer all. The 'men in the nunnery' jape has a long and diffuse literary history: it has even been adapted by women authors for their own utopias, like Millenium Hall and Herland. The ladies' college has also had long currency as a location of erotic fantasy, a place in which the temptation of forbidden fruit mingles with the pleasures of woman-administered discipline. Even Tennyson's The Princess utilizes this sexual undertow. References to it abound today in telephone kiosks and shop windows, whenever prostitutes advertise their services.

In Grub Street, his fascinating study of the sub-culture of hacks and dunces satirized by Pope, Pat Rogers has pointed out how frequently Swift and his circle use the college metaphor to convey the sense of folly institutionalized. Swift's Tale of a Tub, published four years before the Tatler articles, uses a project for an Academy to satirize selected hacks and pedants. Behind the mocking tones of Mr Tatler can be detected the irritation of a threatened writer trying to protect the tools of his trade - education and knowledge - from the claims of upstarts. It is surely of historical significance that in these Tatler articles the upstarts were female.

Who were the women whose follies selected them out for such ridicule? Why were they grouped together? Their association in The Tatler derived from satirical resentment: there was a score to be settled with each.

Mary Astell was (and is still) credited with having written Bartlemy Fair, an attack on, among others, Steele and Swift; Mrs Manley, later to work with Swift on The Examiner, was from July to November 1709 being 'Phoebe Crackenthorpe, a lady that knows everything' in The Female Tatler, a rivalrous scandalsheet to The Tatler. Elizabeth Elstob had just published her first work of Anglo-Saxon scholarship. In it she applauded her own achievement in learning 'English-Saxon', an accomplishment acquired in association with prominent non-jurors clergymen who had refused to take the oath of allegiance to William III. Swift was himself an Anglican clergyman, and feared that non-jurors were trying to set up 'an alternative Church of England'. 
It is most unlikely that the three women were ever in the same room together, although Mary Astell and Elizabeth Elstob were acquainted. Both would have been aware of Mrs Manley's existence, but Mrs Astell and Mrs Manley were to each other what the Church Times and Private Eye are in a reference library: in, but not of, the same world. Augustan society was complex and fragmented; different fractions and factions lived cheek-by-jowl, often in a state of deep mutual hostility. Mrs Astell was a High Church Tory, pious and above suspicion (at least on moral grounds). Mrs Manley once described herself as 'the only person of her sex that knows how to live'. Their juxtaposition must have been a joke in itself.

The daughter of a Royalist soldier who was seduced into a bigamous marriage by her cousin and was forced to support herself by writing best-sellers, Mrs Manley's personal history was as romantic as any novel, as she was herself aware. Like Susannah Centlivre and to a lesser extent Aphra Behn, she has since her death been mainly consigned to the obscurity of a literary curiosity, known only as a footnote to the works of Pope and Swift. Although the importance of Aphra Behn's Orinooko has long been acknowledged, only recently have these women authors begun to be given their due as midwives of the novel through the bastard literary forms they introduced: the romantic history, the political allegory, and so on.

Mrs Manley's neglect can be partly explained by the topicality which made her so successful in her own day. Her most scandalous work, The New Atalantis (which earned her some time in prison in 1709) is very much of its time, but also shares in the general problem of the roman $a$ clef - its readership has to be interested in the people behind the disguises. Without that The New Atalantis is a dull read, but given an interest in the people and a liking for gossip, it springs to life.

There are other reasons as well. Fidelis Morgan, in A Woman of No Character, her 'Autobiography of Mrs Manley', points out that much of her heroine's vilification rests on battles fought beyond the grave. Winston Churchill, for example, called her work 'the lying inventions of a prurient and filthy underworld ... paid for by party interest and political malice'. His invective was provoked by the job she did, as a paid party hack, in washing his ancestor John Churchill Duke of Marlborough's dirty linen in public. Mrs Manley used the gossip surrounding the Duke's early career (which linked his preferments to sexual services rendered to King Charles's mistress, the Duchess of Cleveland) in order to undermine the Churchills' position with Queen Anne. That his distinguished ancestor might have been the Cherubino of his age was clearly an undignified and unacceptable suggestion to an aspirant Prime Minister.

Muck-raking journalists must not expect to be liked, even by posterity. Yet Mrs Manley's prurience was well suited to her time and subject matter. Sex was the great failing of Charles II (as gambling might have been to another king). His sexual needs and interests were manipulated by his political advisers and this process was watched 
with dismay by those outside the court. Andrew Marvell's satire, The Last Instructions to a Painter, written after the incursion of the Dutch up the Medway, depicts an uneasy Charles waking at night to find the anguished ghost of a beautiful virgin naked in his bed; she vanishes at his approach. This seems to the poet a fitting image of England for such a king. During the Restoration, and for a long time after, sex was an affair of state.

A Woman of No Character accepts Mrs Manley on her own terms. The claim that her fictions are mere lies is turned on its head by an interpretation which presents them as a form of realism - 'although she may have embroidered and elevated, she never evaded the truth of her situation' - and which marshals the evidence to support her claims. The reader can therefore be given a generous helping of Mrs Manley's spicy anecdotal style in a narrative culled from The Adventures of Rivella, The New Atalantis and so on. Summaries of Fidelis Morgan's own investigations into Mrs Manley's life and times provide a side-dish.

A Woman of No Character tells us about more women than Mrs Manley. It neatly illustrates that at the end of the seventeenth century, political partisanship was not confined to the male political class, but that women were enlisted amongst the in-fighters. The case of Mary Astell as elaborated by Ruth Perry also makes this clear. Coincidentally it signals (and the Tatler articles confirm) the presence of women in literary relations precisely at the moment in which those relations were being transformed by literature's entrance into the marketplace and a concomitant professionalization of letters.

Such indications challenge over-simplistic claims of women's historic exclusion from literary relations: they were satirized precisely because they were there. It would have been interesting, from this point of view, to have had more on the relationship between Mrs Manley and Mrs Baldwin, the publisher of The Female Tatler and (unlike Mrs Manley) a well-known Whig. There was at this time an unusual coincidence of women writers and women booksellers and publishers. Ruth Perry, in The Celebrated Mary Astell, ascribes some of Mrs Manley's success as a writer to her relationship with the printer John Barber, who printed The Female Tatler for Mrs Baldwin. But this liaison came after Delarivier Manley's career was established, and Fidelis Morgan suggests that her earnings and connections made it a lucrative friendship for him.

Mrs Manley's writings show a marked deference to Aphra Behn, demonstrating how important that writer was as a reference point for other female authors. In The New Atalantis, she seems to be used as an iconic mediator between the writer and her public. Its flimsy plot has Astrea (Aphra Behn) return to Earth and her mother, Virtue. Through the agency of a woman 'Intelligencer', Astrea and Virtue make a conducted tour of polite society, discovering how corrupt it has become through stories of the sexual excesses of various prominent Whigs. It must be an intended irony that these stories are as salacious as any penned by Aphra Behn herself: Astrea is being invoked not just as a 
witness but also as a precedent.

Quite how sexually provocative a writer Aphra Behn could be emerges from a reading of Love Letters Between a Nobleman and his Sister. Its theme is the pursuit of sexual gratification; its main characters betray all sorts of loyalties and perform all sorts of antics in the interest of jouissance and summon up in the process the various offspring of sexual desire: envy, jealousy, deceit, desire for revenge, depression and dissatisfaction. Philander, its hero, is (as his name suggests) interested only in pursuit and conquest. His sister-in-law Sylvia, the heroine, is doomed from the moment she accepts him as her lover and thereby an incestuous love affair. To follow their 'hearts', both are prepared to enter cynically into marriage contracts and are dismayed when expected to honour them. Whilst Philander can perform his manoeuvres yet be re-accepted by polite society - 'being very well understood by all good men' - Sylvia's fate is a life of sexual adventure and exploitation on the margins of society. More casually corrupting than vicious, their story could stand as a perfect illustration of Mrs Manley's description of the effects of love (published thirty years later):

Fame, honour, chastity and glory have no longer their due estimation, even in the most virtuous breast. When love truly seizes the heart it is like a malignant fever which thence disperses itself through all the sensible parts. The poison preys upon the vitals and is only extinguished by death or, by as fatal a cure, the accomplishment of its own desires.

(The Power of Love, 1712).

For love here read sexual passion or lust.

Love Letters is a true fiction. It may be fixed on real characters but its internal dynamic remains independent of its inspiration. Maureen Duffy's new introduction shows the connections between Sylvia and Philander and Lady Henrietta Berkeley and Lord Grey of Werke, her brother-in-law, who eloped in 1682. But aspects of Sylvia's portrayal, in particular her liking for dressing en chevalier, also call to mind a woman whose name flits through the pages of most of these books Hortense Mancini, Duchess of Mazarin.

Born to beauty, power and wealth, Hortense Mancini was the heiress of Cardinal Mazarin. He selected her husband from the French court (having earlier turned down an offer from Charles II), and gave the lucky man Hortense (then aged fourteen), as well as a share in the largest fortune in France and the title, Duke of Mazarin. Unfortunately the Duke proved to be a jealous husband and a religious maniac, ill-matched to a wilful and worldly wife. Six years and four children after their marriage vows in 1667, Hortense and her maid fled France, dressed as men. In 1675 she arrived in England, introduced by Buckingham who hoped to make her Charles II's mistress; she fell in love with someone else and refused Charles. But she stayed in London 


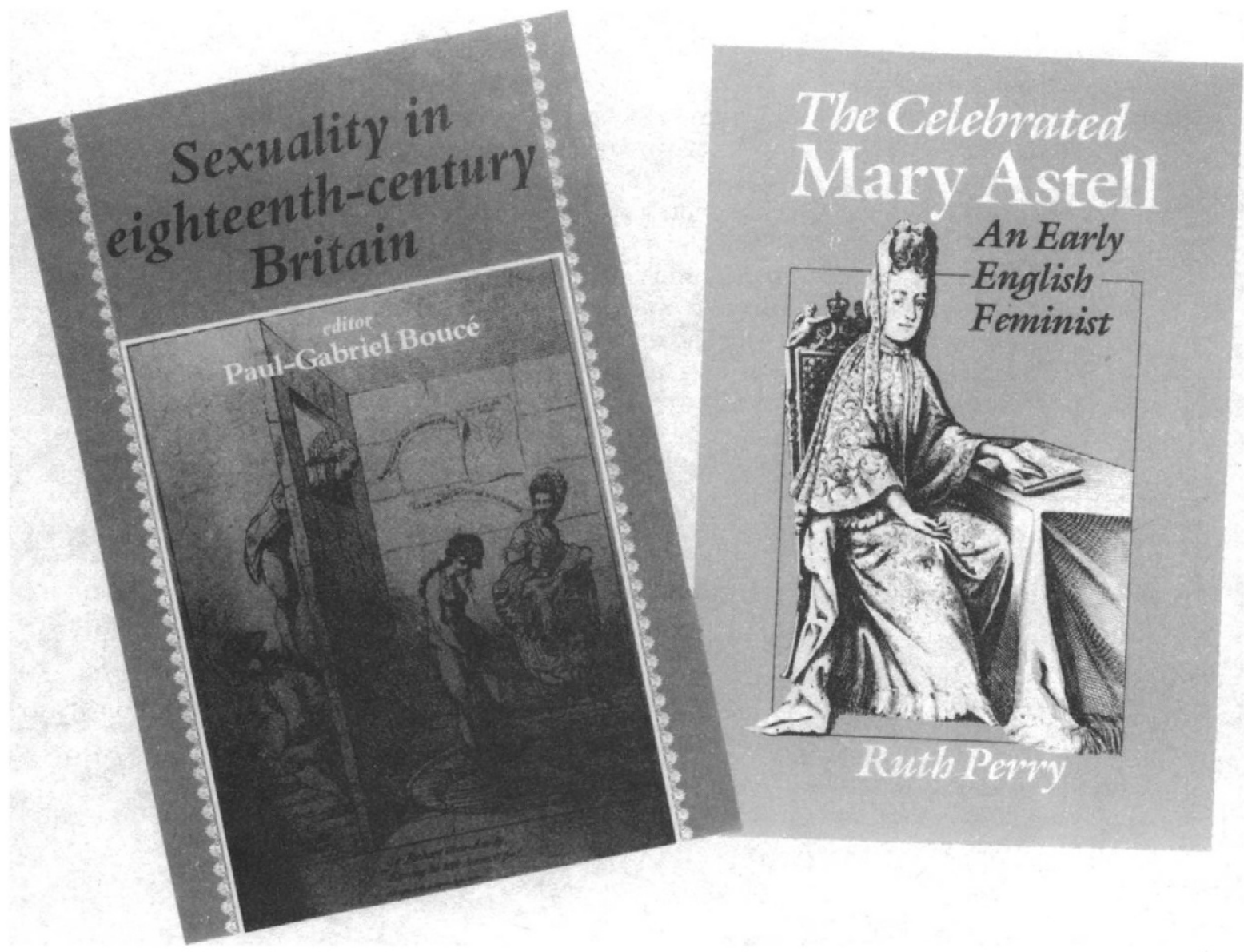

until her death in 1699 , at the age of fifty-three, notorious but well liked.

Publishers took advantage of her death to reissue her unapologetic memoirs and transcripts of proceedings brought against her by the Duke, who had tried in 1689 to get control of her dowry and force her back to France. It was after reading these books that Mary Astell wrote her Reflections on Marriage, now reprinted in full in Bridget Hill's introduction to her work and selections from her writings, The First English Feminist.

There is, in Paul-Gabriel Bouce's rich collection, Sexuality in Eighteenth Century Britain, a fascinating article by Peter Wagner, 'The Pornographer in the Courtroom', which draws attention to the use of divorce transcripts for titillation. The Arguments of Mons. Herard for the Duke of Mazarin is by no means as bawdy as the divorce proceedings of the Duke of Norfolk, published at much the same time: the aim of the Duke of Mazarin was to reclaim his wife, not to divorce her. But both cases have the voyeuristic attraction of scandal amongst the rich and famous. That the Duchess of Mazarin was her neighbour 


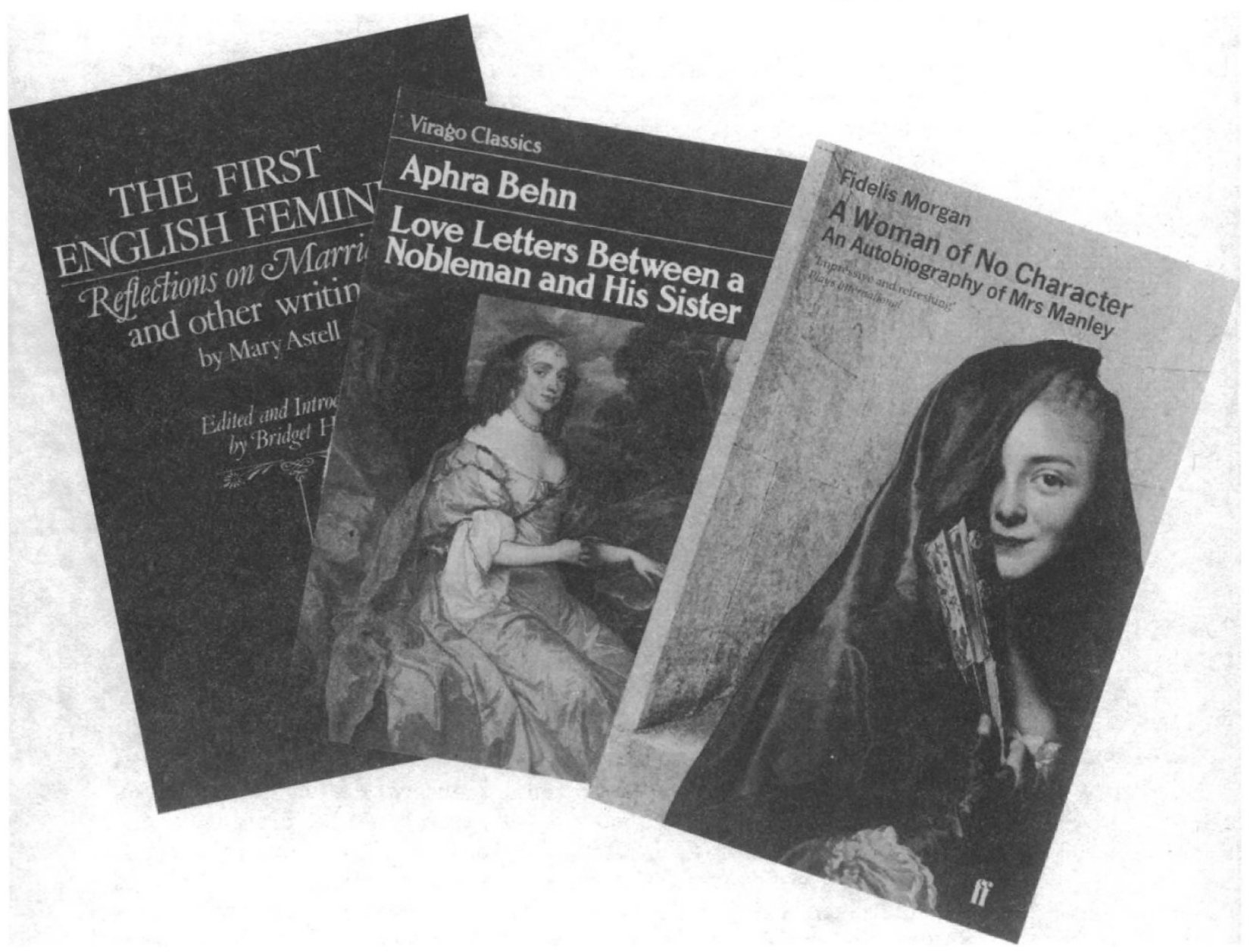

in Chelsea, where she ran a gambling club, must have increased Mary Astell's curiosity.

Mary Astell is sometimes claimed, wrongly, to be the first woman to demand an equal education for women. Her true originality lay in her view that women should have options other than marriage open to them. Reflections on Marriage is a scathing criticism of marriage a la mode and Bridget Hill is right to give it the prominence she does. It brings the reader to the heart of the central contradiction of Mary Astell's outlook: 'how', to quote Bridget Hill, her attachment to the divine right of kings and passive obedience opposes her reluctance to accept women's position as slaves to domestic tyranny'.

The link between the rights of kings and husbands was no dead metaphor. It was argued in law, in the reign of Charles II, that The Husband is the Head of the Wife as fully as the King is Head of the Commonwealth.' Partisan that she was, Mary Astell delighted in pointing out how even those who refused to accept the divine right of kings supported the divine right of husbands: 'not Milton himself wou'd cry up Liberty to poor Female Slaves, or plead for the lawfulness of 
resisting a Private Tyranny'. But these attacks on others cannot hide the fact that as a Stuart supporter she found it impossible to liberate herself from the implications of the linkage claimed.

In the case of the Duchess, she had sympathy for her situation - 'To be yok'd for Life to a disagreeable Person and Temper... to be contradicted in everything one does or says ... to be denied one's most innocent desires, for no other cause but the Will and Pleasure of an absolute Lord and Master ... is a misery none can have a just idea of, but those who have felt it' - but not for her cause. She cannot approve of someone who ran off 'with a spruce Cavalier', nor does she consider her complaints very serious - 'Are the being forbid having Comedies in her House ... dismissing of a Servant, imposing Domesticks, or frequent changing them, sufficient Reasons to Authorize a Women's leaving her Husband...?' The Duchess's adherents demanded the right of separation fron an unreasonable husband, and Mary Astell would have none of that. Whilst she thought that women should have the choice not to marry, and that unmarried women and widows should be treated as free subjects, she also felt that, once married, women should make the best of their lot and look for their reward in the next world.

Quite properly Bridget Hill resists any attempt to smooth out the contradictions and ambiguities, to deny the tensions implicit in such a position. But these contradictory elements are held together by a logic which is under-represented in this volume. This logic is not that of conservatism (as the modern American interpretation of Mrs Astell would have it) but that of absolutism - which is not the preserve of one political standpoint - and, interlaced, the logic of religious mysticism.

In Mary Astell's mental universe the choice between marriage and not-marriage was a choice between absolute masters: man with all his faults and brutishness, or the Godhead. The ideal choice (in all senses of the word) should be for God:

Our very lower Appetites will find more true Satisfaction in the Service of GOD and Reason, than in their own irregular and exorbitant Sway. Sure I am that a Man may be much happier by withdrawing his Heart from the Creature than he can be in cleaving to it ... But admitting the Creature were able to entertain us, what wise Man wou'd think much to relinquish a lesser for a greater good, or shew any Inclination for lower Delights when courted to the Enjoyment of the highest? . . Other Loves, even the very best, have somewhat of Grossness in them which offends even whilst they please, and have always their Pleasure mixed with Pain; whereas Divine Love is so connatural to the true Taste and Relish of the Soul, that ... the sentiments it excites . . . are Sweets that know no Bitter, Joys without Alloy, Pleasures that have no Sting.

Thus she wrote to John Norris, in letters which helped to make her famous, and which were published partly to publicize her Serious Proposal to the Ladies for a religious and educational centre. The reflections on love and desire contained in the Norris-Astell 
correspondence are absent from The First English Feminist, which is a pity because they not only clarify the position from which she proposed her alternative to marriage but also help the modern reader to understand why she was perceived as a demi-Catholic by her contemporaries - by the admiring Norris, who compared her to St Teresa, by alarmed Anglican bishops who recommended women not to support her schemes, and by the satirists of The Tatler.

To critics and admirers alike, Mary Astell's writing represented a call to celibacy. How to interpret this call has given students of her work headaches ever since. In her essay 'The Veil of Chastity', reprinted in Sexuality in Eighteenth Century Britain, Ruth Perry tried out a rationalistic explanation: celibacy was the understandable reaction of any reasonable women to the perils of death by childbirth risked in the marriage bed. This argument gives scope to a compelling discussion of childbirth and its complications during Mary Astell's lifetime, but ultimately founders because there is no evidence that it was ever used by Mary Astell herself.

Ruth Perry's new biography, The Celebrated Mary Astell, eschews such explanatory attempts in the interest of providing a fuller picture of Mary Astell's life than has been hitherto available. Her research has thrown up important new material which reveals Mary Astell as an active Jacobite, highlights her dependence on patronage and links her silence as a published author after 1709 (she died in 1731) to her involvement with the school attached to Chelsea Hospital. Bridget Hill attributes this silence, less convincingly, to disappointment at 'the failures of the causes into which she had put all her energies'. Ruth Perry demonstrates that the links between The Society for the Propagation of Christian Knowledge and High Church Jacobites would have made the charity school in Chelsea a point of intersection of all of Mary Astell's causes.

The Celebrated Mary Astell is a product of assiduous research and undoubted devotion to the figure of Mary Astell. It is sure to become the standard work of reference. But the single-minded search for a 'pioneering feminist thinker' has resulted in an unhelpful aggrandizement of her subject.

In the late seventeenth century there was a general debate, in different milieux, about the need for the education of women. Ruth Perry has not been able to resist the temptation to claim for Mary Astell supreme intellectual leadership in this debate, and she writes as if all contemporary arguments for female education derived from hers. Thus Defoe is accused of having stolen her idea for a women's academy for his Essay Upon Projects, without any evidence to support this claim. Other similarly unsubstantiated and questionable statements are made. She asserts that:

Such women as Judith Drake, Lady Damaris Masham, Elizabeth Thomas, Lady Mary Chudleigh, Elizabeth Elstob and Lady Mary Wortley Montagu - these we know of - were encouraged by her book to think of 
women as a misunderstood and oppressed class of people. Their lives were changed by Astell's texts and by her example; she showed them how to take themselves seriously as thinkers and writers.

Yet do we know this? Judith Drake may or may not have been author of An Essay in Defence of the Female Sex, published two years after A Serious Proposal. The philosophical position from which this essay is written is quite different from that of Mary Astell, as are its main questions and conclusions. There is no reason to treat its author as an acolyte or 'imitator', to use Ruth Perry's term. Lady Masham, the well-educated daughter of Ralph Cudworth and one-time friend of John Norris, gave a home to John Locke and corresponded with Leibniz. She published criticisms of sentiments expressed in the Astell-Norris correspondence (criticisms wrongly attributed by Astell to Locke). She also published her own thoughts on the education of women, in which she stressed (as did Defoe) the important educative function of mothers. There is no suggestion in her work that she felt she owed anything to Mary Astell.

This tendency to present speculation as fact constantly detracts from the valuable work Ruth Perry has done. Confusions and difficulties, like those of determining authorship of works unsigned or given pseudonyms, tend to be smoothed out. That it is by no means certain that Judith Drake wrote An Essay in Defence of the Female Sex, for example, is nowhere pointed out. For a careful analysis of the problems of determining the authorship of this essay and its relationship to the work of,Mary Astell, readers still need to turn to Florence Smith's Mary Astell, first published in 1916.

Ruth Perry is unnecessarily dismissive of her predecessor's 'antiquarian' interests; more enthusiasm for matters bibliographical would have improved her own book. Whilst there is a useful checklist of the availability of Mary Astell's works in American libraries, a similar checklist for British libraries could help American as well as European readers. And the absence of a list of works consulted is a startling omission, particularly when space is given, with no accompanying explanation, to the publication of Lady Elizabeth's Hastings' Luncheon Menus and Table Maps. Lady Betty Hastings was a friend and benefactor to Mary Astell, but her menus, entertaining as they are, make an odd appendix to a life of someone who was, we are assured, well-known for her abstinence.

\section{NOTE}

Rosalind Delmar has recently contributed to What Is Feminism (Blackwell 1986) and is currently working on a history of feminist ideas. 